\title{
Соотношение категорий целостности, длительности, определенности и интервала в глаголах совершенного вида
}

\author{
ЙОЖЕФ КРЕКИЧ \\ KRÉKITS József, H-6800 Hódmezővásárhely, Szivárvány utca 25. \\ E-mail: krekits@t-online.hu
}

(Received: 17 April 2015; accepted: 12 June 2015)

\begin{abstract}
The cooperation of various disciplines and theories is supposed to be used in most cases in cognitive research. In this study, the author aspires to separate the essential and the accessory (the coalescence and the compound) meanings. A differentiation of the essential meaning is made in the starting, finitive, delimitative, and resultative meanings. The analysis made it possible to separate the external and internal meanings.
\end{abstract}

Keywords: aspectology, Russian, perfective verbs, totality, duration, determination, interval

«Мы считаем, что более мудр во всякой науке тот, кто более точен и более способен научить выявлению причин...» (Аристотель: Кн. 1. Гл. 2).

Комментарии излишни.

1. С результатами нашего исследования хорошо перекликается плодотворная мысль Ференца Паппа о том, что для категории вида характерно, что она помимо морфологических признаков, выражается в широком смысле синтаксическими средствами (БолЛА-ПАЛЛ-ПАПП 1968: 366, РАРP 1979: 228). Подходя к данному вопросу чисто теоретически, следует признать, что без учета «синтаксических средств», т. е. вербального и ситуативного контекста немыслимо изучение аспектуальных значений. Следует ясно осознать, что один лишь морфологический критерий в изучении глаголов оказывается явно недостаточным, необходимо изучать и окружение глаголов (АникинА 1964: 165, КРЕКИч 1989: 9).

1.1. Ю. Д. Апресян ставит вопрос о том, может ли синтаксис оказывать обратное воздействие на семантику слов, видоизменяя ее. «На этот вопрос следует ответить утвердительно», - подчеркивает он в главе под названием «О давлении синтаксиса на семантику» (АПРЕсян 1974: 29).

1.2. В ходе нашей исследовательской работы мы могли убедиться в том, что в речи значение одного и того же глагола в зависимости от внутренних и внешних факторов, от значения приставки и производящего глагола, от коннотативных (прагматических) оттенков значения, от конситуации может измениться. Изучая функции временно-предельных глаголов, мы постепенно пришли к заключению, что границы между группировками разных способов действия подвижны, что акциональные значения глаголов в зависимости от 
морфологических, синтаксических, от семантических и прагматических факторов, часто смешиваются или переходят друг в друга.

2. Философские учения об онтологических основах русских глаголов стали известными благодаря трудам Ю. С. Маслова (1948) и А. В. Бондарко (1967). Их предысторию можно возвести к Аристотелю, который в своей книге различает следующие категории: субстанцию, время, количество, качество, место, ситуацию, действие, состояние, претерпевание, изменение и соотношение между ними (АРистотеЛь: Кн. 1. Гл. 2).

3. Чтобы значение глагола соответствовало действительности, мы не должны отвлекаться от изучения субстанциальных явлений ситуации, от рассмотрения предметов, вещей и лиц, потому что «предметы составляют субстанцию мира» (WITTGENSTEIN 1989: 13).

3.1. Аспектологи еще не отличали внутренние значения от внешних значений, от так называемых независящих от контекста значений и от зависящих от контекста, что предполагает изучение и обнаружение гетерогенных и гомогенных в них значений.

3.2. Прежде всего мы ставили перед собой цель рассмотреть и интерпретировать «двойную теорию» А. Бергсона (см. BERGSON 1923). Своей двойной теорией Бергсон разработал теоретические основания категории длительности (по-иному: категории протяженности). Без обнаружения его непоследовательностей и противоречий нельзя точно отличить друг от друга внутренние и внешние значения.

Исследовать истину в одном отношении трудно, в другом легко. Это видно из того, что никто не в состоянии достичь ее надлежащим образом... Так что и наиболее истинно то, что для последующего есть причина его истинности... (АРИСтОТЕЛЬ: Кн. 2. Гл. 1).

Комментарии излишни.

4. В последнее время возобновились споры о вечном вопросе аспектологии, об общем (или: инвариантном) видовом значении глаголов совершенного вида. Инвариантное значение глаголов СВ толкуется по-разному; не удалось создать единой концепции, добиться тождества взглядов. В данной статье мы задались целью найти ответы на вопросы, поставленные специалистами в последнее время: как соотносятся понятия целостности, длительности, интервала, определенности в значении глаголов СВ, как соотносятся эти определения, как дополняют друг друга с точки зрения теории и языка.

4.1. Мало внимания обращается и на дотрадиционную категорию onpeделенности/неопределенности, изложенную известным теоретиком А. Мейе (см. MeILlet 1924). Ю. С. Маслов подчеркивает, что теория происхождения совершенного и несовершенного вида возникла из индоевропейской категории детерминированности/индетерминированности (по-иному: определенности/неопределенности) действия. Эта теория представляется ему наиболее удачной из всех, предложенных по интересующему его вопросу, наиболее близкой к истине (МАслов 1958: 11). 
4.2. В нашей исследовательской работе мы использовали термин А. Мейе определенность в значении «ограниченность», всегда подчеркивая в его корне слово предел (Крекич 1989: 16). В этом же значении сформулировал Мейе семантику детерминированного и индетерминированного вида.

4.2.1. В аналогичном духе излагает Мейе определенные перфективные и неопределенные имперфективные значения интервала: «l'aspect déterminé... indique un procès qui aboutit à un terme défini» [определенный аспект... обозначает такой процесс, который доходит до предела]; «l'aspect indéterminé... indique un procès qui se poursuit sans terme défini» [неопределенный аспект... обозначает такой процесс, который без достижения конечного пункта далее продолжается〉] (MEILLET 1935: 249).

4.2.2. Мы согласны с А. Б. Аникиной, которая считает необходимым подчеркнуть, что само понятие длительности действия может быть передано и глаголами СВ. «Но это всегда будет длительность, ограниченная какимилибо границами во времени или другими факторами, вносящими определенность в характеристику действия〉 (АникинА 1964: 172). Эта определенность (y A. Мейе - «детерминация») может быть внутренней и внешней (MEILLET 1924). Данное разграничение мы считаем нужным для объяснения различия внутривидового (т. е. языкового) значения и обусловленного внешним контекстом значения.

Опираясь на эти взгляды, мы различаем:

а) внутреннюю временную определенность - внешнюю временную определенность действия или состояния;

б) внутреннюю количественную определенность действия или состояния - внешнюю количественную определенность действия;

в) внутреннюю качественную определенность - внешнюю качественную определенность действия или состояния.

Если категории разделяются на сущность, качество, место, действие или претерпевание, отношение и количество, то должно быть три вида движения: для качества, для количества и места. По отношению к сущности нет движения, так как нет ничего противоположного сущности (АРистотель: Кн. 11. Гл. 12).

Аристотель создает свою дихотомию, которая состоит из главной и побочной части ситуации, из внутреннего и внешнего значения. Он считает очень важным отделять главное значение от побочного. В своей «Метафизике» мыслитель подчеркивает, что наука занимается в первую очередь общим, т. е. главным значением. Его двойственная теория отличает главную часть ситуации, эссенциальное значение от добавочного (акцидентального) значения.

5. Прежде чем приступить к разрешению некоторых нерешенных до сих пор проблем, нам предстоит выяснить, как соотносятся между собой термины целостности, длительности и интервала, как они поясняют друг друга, как они выявляют значение, как они способны передавать целостность, длительность, или их проявление в форме интервала. 
6. Для того, чтобы лучше понять проблему соотношения (взаимоотношения) приведенных нами терминов, мы далее перечислим и коротко объясним главнейшие из них:

- Интервал: часть между двумя пределами, между предельными пунктами времени или действия.

- Граница: конечная точка времени или действия, предел.

- Длительность: чистая настоящая длительность и нечистая длительность.

- Акцессорное (акцицентное) значение: дополнительное, второстепенное, побочное, сопроводительное - их общее значение: добавочное, добавка.

7. Дж. Грубор, полемизируя с С. Карцевским, заявляет, что категория определенности совпадает с категорией перфективности: «Одређеност опћенито призната перфективности» (Груьор 1953: 192). Польский лингвист, Э. Кошмидер, при анализе так называемых «аспектуальных ситуационных типов» исходит из оппозиции «наступления» (Eintritt) и «длительности» (Währen) (Koschmieder 1934: 224). В своей формулировке Э. Кошмидер выдвигает левую границу перфективного действия, не отрицая при этом целостного проявления перфективного действия: «Das perfektive Aspekt... drückt aus, dass das Ausgesagte von Sprechendem als Ganzes [курсив - Й. К.] betrachtet wird» (KosCHMIEDER 1929: 104).

Из вышеизложенных взглядов выясняется, что Мейе свое внимание сосредоточивает на правой границе действия, в то время как Кошмидер устремляет свое внимание на левую границу действия (или ситуации).

7.1. С точки зрения философии и языка наиболее приемлемые определения можно связать с именами Ю. С. Маслова и Ференца Кифера (МАслов 1959: 221, KIEFER 2000a: 276-277).

7.2. На обе границы перфективного действия обращает наше внимание Маслов, по мнению которого перфективный глагол передает действие «в своей неделимой целостности» (МАслов 1958: 9). А. В. Бондарко совершенно прав, когда он отмечает, что «значение неделимой целостности следует понимать, прежде всего, как невозможность деления действия на отдельные фазы» (БондАРко-БулАнин 1967: 31), т. е. глаголы совершенного вида представляют собой (поскольку невозможно делить их на отдельные фазы) интервал времени, т. е. длительность (протяженность) времени. Это значит, что перфективный глагол ограничивает действие с двух сторон, справа и слева, в то время как границы имперфективного глагола стираются (размываются), потому что имперфективное действие нецелостно (МАслов 1958: 9).

7.3. Что касается инварианта глаголов $\mathrm{CB}$, нет противоречия между вышеизложенным высказыванием Маслова и истолкованием Кифера, который с философской и математической точностью выясняет различие между перфективными и имперфективными видами. По мнению Ф. Кифера, «событие является перфективным, если событийное действие относится только ко всему данному интервалу, или другими словами, данный интервал не имеет в себе ни одной такой части, ни одного делимого, к которому событийное 
действие могло бы быть отнесено в отдельности. [...] Об имперфективном действии идет речь, если событийное действие относится к большей части промежутков делимого интервала» (KIEFER 2000a: 276).

7.4. В процессе исследования возникали новые вопросы: в частности, какие свободные от контекста или какие зависящие от контекста значения фиксируются ситуациями, выраженными имперфективными глаголами, какие перфективными. Мы согласны с Ф. Кифером, утверждающим, что «когнитивная лингвистика не представляет собой новую парадигму, которая предназначена для того, чтобы сменить более ранние теории» (KIEFER 2000b: 127). «Действительно, мы не должны стремиться к описанию одного только свободного от контекста значения, но следует также стремиться к описанию внешнего значения, зависящего и от контекста. Когнитивные точки зрения это основные части существующих теорий, и их существенная роль в языковой теории состоит в том, чтобы они открыли новые перспективы для описания языка» (KIEFER 2000b: 121-122).

7.5. Трактовки Маслова, Кошмидера и Кифера о вопросе целостности (интервального проявления действия) приближают нас к пониманию категории определенности/неопределенности, которая играет важную роль в осмыслении внутренних и внешних значений глаголов совершенного вида.

8. В. Поллак оказывается прав, когда утверждает, что при изучении видов «синтаксический компонент» имеет такое же определяющее значение, как и «морфологический», ведь морфология есть какой-то «окостенелый синтаксис» (erstarrte Syntax) (PollaK 1962: 20).

8.1. Относительно целостного проявления действия проблему представляют глаголь начинательного способа действия. Что касается их значения, возникает вопрос, как осуществляют они целостность проявления действия? На наш взгляд, глаголы начинательного способа действия состоят обычно из двух частей: из главной, существенной части, из значения наступления действия и из добавочной части (акцессорной части), которая передает импликацию значения начинательного глагола (который способен воспроизводить в своем окружении импликационное значение), т. е. продолжение, которое мы считаем не обязательным.

Два значения находятся в соприкосновении в начинательном глаголе: первое - существенное, которое обозначает наступление действия, второе акцессорное, которое фиксирует продолжение действия. Наступление действия является исходным пунктом начала действия. Здесь еще придется определить значение момента, что даже для многих лингвистов оказывается проблематичным.

Миг, мгновение или момент имеют значение «очень короткий промежуток времени» (МАС 1982). Слово промежуток в словаре С. И. Ожегова толкуется словом интервал или словосочетанием «время, разделяющее чтолибо» (ОжЕГОВ 1983). Промежуток, или интервал, каким бы коротким он ни был, всегда предполагает середину действия, неотделимую от начала и конца перфективного действия. Таким образом, моментальность и целлост- 
ность не исключают друг друга. На наш взгляд, даже моментальные глаголы могут иметь и немоментальное значение. Легко заметить, что одноактные глаголы в плане повествования часто вводят прямую речь - более или менее длинное высказывание:

(1) Азазелло наклонился к ней и шепнул|многозначительно: - Hy, интересто очень большой... Вы воспользуетесь случаем... (М. Булгаков: Мастер и Маргарита).

Словесный контекст тоже может указывать на протяженность (длительность) проявления действия одноактных глаголов:

(2) Она тяжело и продолжительно |вздохнула, как будто... приготавливаясь к длинному разговору (Л. Толстой: Война и мир).

9. В своей книге Б. Рассел попытался применить самый новый метод. Автор заявляет, что существует метод, с помощью которого мы сможем постепенно приближаться к истине, и что при этом каждый новый момент будет вытекать из дальнейшего развития, а не из выкидыша прежнего (RUSSELL 1994: 681).

Исследовать истину в одном отношении трудно, в другом легко. Это видно из того, что никто не в состоянии достичь ее надлежащим образом... Верно также и то, что философия называется знанием об истине. В самом деле, цель умозрительного знания - истина, а цель знания, касающегося деятельности, - дело: ведь люди деятельные даже тогда, когда они рассматривают вещи, каковы они, исследуют не вечное, а вещь в ее отношении к чему-то и в настоящее время... (АРИСТОТЕЛЬ: Кн. 2. Гл. 1).

Чтобы уловить значение глагола в точном соответствии действительности, мы не должны отклоняться от изучения субстанциальных элементов ситуации, потому что предметы составляют субстанцию мира (WITTGENSTEIN 1963: 115), следовательно, вскрытие значения глагола немыслимо без изучения тех элементов, которые участвуют в ситуации, т. е. без изучения так называемых аспектуальных актантов. Если в значении глаголов СВ на первый план выдвигается аспектуальный актант (субстанциальный элемент перфективной ситуации), тогда речь идет о результативно-предельных глаголах (КРЕКИЧ 1978: 114).

10. В дальнейшем рассмотрим на некоторых примерах в определенном порядке (время, действие, аспектуальный актант), как осуществляют глаголы СВ длительно-образные и процессо-образные значения в своем внутреннем и внешнем составе.

10.1. Во временно-предельных глаголах на первый план выдвигается «время». Возникает вопрос: как ведут себя точечные глаголы по отношению к категории длительности? По мнению М. Я. Гловинской, «точечность» несет в себе только два фазисных элемента: начало и законченность, которые 
в значении перфективных моментальных глаголов совпадают. Недостает в них середины действия, поэтому в значении моментальных глаголов целостное проявление действия терпит ущерб (ГловинскАя 1998: 128-129).

По-другому высказывается о данной проблеме в своей монографии известный финский философ Г. Х. фон Вригт, который подчеркивает, что «темпоральная последовательность предполагает, что мы в состоянии отделять моменты (occasions) друг от друга во времени. Но момент имеет также длительность [курсив - Й. К.], которая является его длиной или ,размером“» (Вригт 1986: 525).

Наиболее точную интерпретацию дает немецкий словарь Дуден (1989): Moment - «sehr kurzer Zeitraum». Такая интерпретация предполагает и середину действия, которая неразделимо срастается (сливается) в единое целое с началом и конциом перфективного действия. Из всего этого можно сделать вывод, что моментальность и целостность (тотальность) не исключают друг друга. Сюда относятся главным образом семельфактивные глаголы (крикнуть, прокричать).

В рассматриваемом вопросе мы полностью согласны с А. Бергсоном, который приводит примеры, чтобы наглядно доказать, что моментальные глаголы способны передавать целостные действия: «Математик идеализирует nункm, который в действительности никогда не бывает без протяжения...» (cM. BERGSON 1923).

10.2. «Каждое употребление слова, - пишет Ш. Карой, - выдвигает одни элементы значения слова на первый план, другие отодвигает на второй план» (KÁROLY 1970: 181). К этому еще необходимо добавить, что некоторые актуальные значения в зависимости от коммуникативных потребностей говорящих встречаются чаще, другие - реже; самые типичные актуальные значения, встречающиеся наиболее часто, называем прототипическими значениями, все остальные - побочнылми значениями.

10.3. Среди философов распространен взгляд, согласно которому в мире все рождается из противоположностей. Теория двойственности направлена на то, чтобы отграничить в ней существенное от несущественного, т. е. от добавочного, потому что наука занимается лишь общим, центральным. Здесь уместно вспомнить, что о прагматических аристотелевских традициях напоминает нам О. Хевизи. В своих замечаниях о прагматике он воспринимает прагматику в широком смысле, отмечая, что первые шаги прагматики были сделаны уже в аристотелевском учении (HÉVIZI 2013: 208).

11. Чтобы облегчить ориентацию в терминологии, будет небесполезно перечислить все потенциально противостоящие термины, на основе которых рождаются новые и новые теории о длительно-образных и процессообразных значениях и элементах языка (см. KRÉKITS 2011): 


\section{Длительность}

1. Чистая, свободная от смешений значений.

2. Длительность не развивается.

3. Длительность гомогенна.

4. Для длительности характерна статика.

5. Моменты длительности присоединяются друг к другу (reihen aneinander).

6. Длительность неразрывна с тем, что длится.

7. Для длительности не характерен признак сукцессивности, постепенности.

8. Для длительности характерна персистенция.

9. Перманентность

10. Количественное значение.

11. Неконтролируемость ситуации.

12. Неактивный субъект.

13. Повторение не позволяется.

14. Конструкция не трансформируема.

15. Имеет атерминативное значение.

16. Передает абстрактное значение.

17. Передает актуально-длительное значение.

18. Передает неактуально-длительное значение.

\section{Процесс}

Смешивается с побочными (акцидентальными) элементами.

Процесс развивается.

Процесс гетерогенен.

Для процесса характерны динамика, подвижность, размах.

Моменты процесса соединяются, цепляясь друг за друга (greifen ineinander).

Процесс образовывается, продвигается, развертывается, развивается, протекает. Процесс характеризует постепенность.

Акцидентальное значение (смешивается с акцидентальными элементами). Изменение.

Качественное значение.

Контролируемость процесса.

Активный субъект.

Повторение позволяется.

Конструкция трансформируема. Имеет терминативное значение. Передает конкретное значение. Передает актуально-процессное значение.

11.1. С точки зрения методологического подхода мы и сегодня считаем полезным разъединение аристотелевской двойственности, отделение существенного значения от несущественного, т. е. разъединение эссенцииального значения от акцидентных значений, как это предлагает нам вслед за Аристотелем венгерский философ П. Болбериц (ср. BOLBERITZ 1985: 66).

11.2. Важную проблему представляют начинательные глаголы с тех пор, как в нашем сознании появилось представление о продолжении наступившего моментального (т. е. точечно-начинательного) действия. Целостным воспринимается обычно первая часть начинательной ситуации, вторая часть отодвигается на второй план. Она передает лишь добавочное, акцессорное значение. В значении точечно-начинательных глаголов на первый план выдвигается «время» наступления действия, «действие» отодвигается на второй план. С. Агрелль называет начинательные глаголы ингрессивами, в значении которых время наступления действия закончено: «Was sie als vollendet fixieren, ist der Anfang der Tätigkeit, worauf noch eine längere Handlung folgt» (AGRELL 1908: 79). Заканчивается только время наступления действия, а не 
действие, которое продолжается, ведь начало действия в состоянии имплицировать продолжение. А. Белич акцентирует законченность начального момента и точечный характер действия: «Auch hier wird ein Moment bezeichnet, der abgeschlossene Moment des Beginnens der Handlung» (BELIĆ 1924: 2). Дж. Грубор воспринимает начальную часть как целостный момент действия: «Prima pars actionis perfecta est» (Груьор 1953: 172). М. А. Шелякин обращает внимание на определенность времени начала действия, на двусторонние границы момента наступления действия (SCHELJAKIN 1969: 108).

Й. Юхас первым обратил внимание на контекстуальное исследование начинательных глаголов, указывая на окружение слов, выражающих адвербиальные отношения (ЮхАС 1962: 36). На точечный характер проявления ингрессивного («точечно-начинательного») действия, на внезапное наступление действия указывают следующие факультативные лексические индикаторы: тотчас, тотчас же, сейчас, сейчас же, сразу, сразу же, разом, вдруг и равнозначные им конструкции или сочетания, как, например, в этот момент, в эту минуту, в ту же секунду и т. п.:

(3) Тотчас же заиграли|как будто испуганные слова... (М. Горький: Жизнь Клима Самгина IV. 84).

В эту минуту зазвонил|телефон (Е. Тершански: Приключения тележки, 76).

11.3. Из приведенных примеров выявляется, что перечисленные наречия и предложные сочетания располагаются, как правило, в виде акциидента перед начинательным глаголом в начале предложения и указывают на момент наступления действия. Нам хотелось бы отметить то, что данные наречия и именные предложные конструкции тесно связаны извне с начинательным глаголом, представляющим собой главную «семантическую форму, что естественно не преуменьшает ее роль когнитивной семантики, которая, как мы видим, занимается интерфейсом между С и Л» (KIEFER 2000b: 121).

11.4. В статье, вызвавшей в свое время много толков, Ю. С. Маслов предупреждал, что в семантическом исследовании глагольного значения недостаточно одного рассмотрения видов только в морфологическом плане, нужен и синтаксический критерий. Таким критерием должно быть «различие между глаголами по их способности вступать в определенные словосочетания, т. е. различие ‘валентности’ изучаемых глаголов» (МАслов 1948: 305).

Предмет настоящего рассмотрения - сущность, ибо мы ищем начала и причины сущностей. И если все в совокупности есть как бы некоторое целое, то сущность есть первая часть его; и если все в совокупности рассматривать как последовательный ряд, то и в этом случае сущность - первое, затем следует качество, потом - количество (АРИСтотЕЛЬ: Кн. 12. Гл. 1).

В своей «Метафизике» Аристотель отличил главное, т. е. существенное значение от добавочного (периферийного) значения. Добавочное значение может быть акцессорным, акцидентным, т. е. дополнительным, второстепенным, случайным или же сопроводительным. Аристотель называет их общим 
именем - добавочными. При определении их значений мы должны отличать главное, т. е. существенное значение от противоположных ему периферийных.

11.5. Как мы уже упоминали, среди философов был распространен взгляд, согласно которому все рождается, возникает из противоположностей. Теория Аристотеля направлена на то, чтобы разъединить эту двойственность, отделить главное, существенное значение от несущественного, так как наука занимается всегда общим, т. е. центральным значением (передающим сущность). К подлежащему принадлежит все остальное только добавочно (акцидентно).

11.6. Проблему представляют начинательные, финитивные и результативные глаголы, в значении которых может осуществиться и двойственность «совпадения противоположностей» (coincidentia oppositorum). Выясняется, что ингрессивные и эгрессивные действия состоят из двух частей: ингрессивные из точечного момента наступления и из части имплицируемого началом продолжающегося действия (начало может имплицировать продолжение, но это не обязательно); эгрессивные - из точечного момента прекращения и из пресуппонированного глаголом предшествующего процесса. Инвариантное общее видовое значение глаголов совершенного вида, целостное проявление действия обнаруживается в семантике ингрессивных (точечно-начинательных) глаголов в самом моменте наступления действия, а в значении эгрессивных (точечно-финитивных) глаголов - в самом моменте прекращения предшествующего ему процесса:

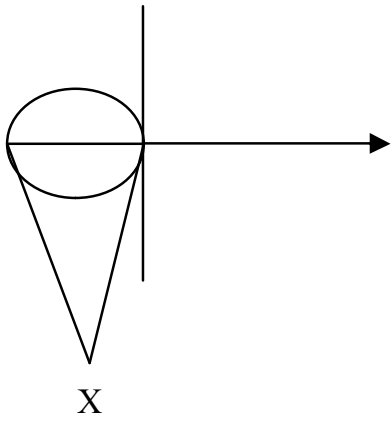

ингессивное действие

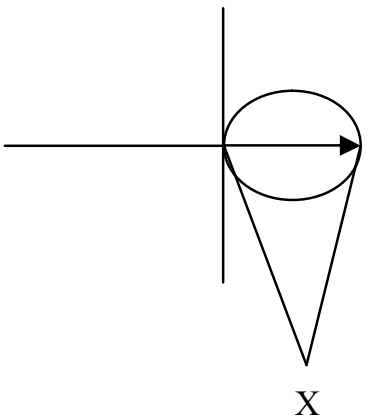

эгрессивное действие

11.7. Итак, значению точечно-начинательных глаголов противостоит значение точечно-финитивных глаголов, которое перемещает фокус внимания на конечный (т. е. определенный) момент действия. Предшествующая конечному моменту процессуальная часть эгрессивного действия является пресуппозицией (т. е. смысловым компонентом) эгрессивной ситуации, выражающей наступление конечного момента действия (4), (5):

(4) - Тебя-то уж отпоминали, как Гришку моего... (М. Шолохов: Тихий Дон, III. 60).

(5) - Тебя-то еще не отпоминали, как Гришку моего... 
Пресуппозищия:

(6)' Тебя поминали

(7)' Тебя поминали
Значение:

и перестали поминать. и не перестали поминать.

Анализ этих примеров достаточно наглядно показывает, что «различия между пресуппозицией и значением в собственном смысле слова проявляется, например, в том, что они по-разному реагируют на отрицание: в область действия отрицания попадает только значение, но не пресуппозиция» (АПРЕСЯН 1974: 29).

11.8. В значении славянских результативно-предельных глаголов кроме прямого объекта важную роль выполняют еще косвенный объект и подлежащее, обязательная и факультативная валентность глаголов, которые мы называем обобщающим термином «аспектуальный актант» (КРЕКич 1978: 114). Чтобы значение глагола точно соответствовало действительности, мы не должны отвлекаться от изучения субстанциальных элементов ситуации, потому что предметы составляют субстанцию мира (WITTGENSTEIN 1963: 115), следовательно, вскрытие значения глагола немыслимо без изучения тех предметов, дел и лиц, которые участвуют в ситуации, на что наше внимание уже обратил Аристотель, придавая этим важность субстанции, которая «при возникновении (зарождении) и при кончине претерпевает изменение» (АРистоТЕЛЬ: Кн. 3. ГЛ. 5).

В значении русских перфективных глаголов могут развиваться три семиологически релевантных компонента: 1) действие, 2) время, несубстанциальные элементы глагольного значения, 3) аспектуальный актант, субстанциальный элемент глагольного значения. Под аспектуальным актантом мы понимаем то лицо или предмет, которые в предложении выполняют либо объектную, либо субъектную функции, характеризующие глагол - по словам Кацнельсона - «изнутри» (КАцнЕльСон 1972: 44). Подчеркнем, что мы такой точки зрения вовсе не принимаем. Совершенно прав Дж. Грубор, когда он утверждает, что действие может быть полностью закончено, а результата нет, так как результат зависит от факторов, лежащих «вне действия» (ГруБор 1962: 74), т. е. от аспектуального актанта, претерпевающего качественные или количественные изменения. Подчеркнем, что факты доказывают, что аспектуальные актанты характеризуют результативный глагол извне, а не изнутри.

11.9. Подобно 3. Вендлеру (VENDLER 1967), Дж. Грубор результативнопредельные глаголы причисляет к глаголам исполнения. «Пантивни: постепено радња извршена сва, од почетка до краја, или који било њезин одређени дио сав» (Груьор 1953: 16). По характеру действия глаголы исполнения осуществляют процессное и результативное действие трояким образом:

1. креативно:

гради кућу строит дом

саградио |кућу (сву) построил|дом (весь)

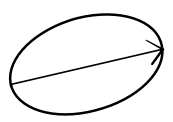

Studia Slavica Hung. 60, 2015 
2. трансформативно:

бели кућу

белит дом

обели | кућу (сву)

выбелил|дом (весь)

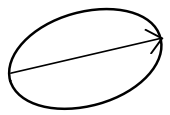

3. мотивно:

враћа се

возвращается

врати се | из сајма

возвратился | с ярмарки

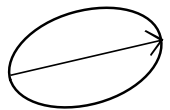

11.10. Чтобы правильно определить довольно диффузное значение делимитативов, мы считаем необходимым отграничить их эссенщиальное значение от акцессорных значений, т. е. отграничить, отличить главное, существенное от несущественного, от акцессорного, добавочного. Эссенциальным (т. е. самым обобщенным) значением делимитативов воспринимается нами деминутивность, деминутивная функция приставки по-, уменьшительное воздействие которой может распространяться либо на время (поработать часок), либо на действие (не очень пошуметь), и, кроме того, на аспектуальный актант (поколоть дровишек. Добавочная часть предложения может входить в соприкосновение с главной, эссенциальной частью либо словами (8), либо предложение-образными конструкциями (9):

(8) - Я немножко $\mid$ nоучусь в гимназии и тоже|стану петь с гитарой, только в черном платье (М. Горький: Жизнь Клима Самгина, I. 30).

(9) - Позанимай|гостя, пока я с Никитой Федоровичем на платье себе|выберу... (А. Софронов: Сердце не прощает, 35).

Кроме того, [при изменении] есть нечто постоянно пребывающее, противоположное же не пребывает постоянно, значит, существует нечто третье помимо противоположностей, а именно материя. Если же видов изменений четыре или сути, или качества, или количества, или в отношении «где», а изменение определенного нечто есть возникновение и уничтожение в безотносительном смысле, изменение количества - рост и убыль, изменение состояния - превращение, изменение места - перемещение, то каждое из этих изменений есть переход в соответствующую противоположность (АРистотЕль: Кн. 12. Гл. 2).

Противоположность - это различие, а различие - это сущность другого рода. Наиболее убедительную интерпретацию предоставил нам Аристотель, заявив, что возможность и действительность являются противоположностями, но не абсолютными, а сравнительными.

12. Противоположные значения глаголов. Многие философы утверждают, что в мире все рождается из противоположностей:

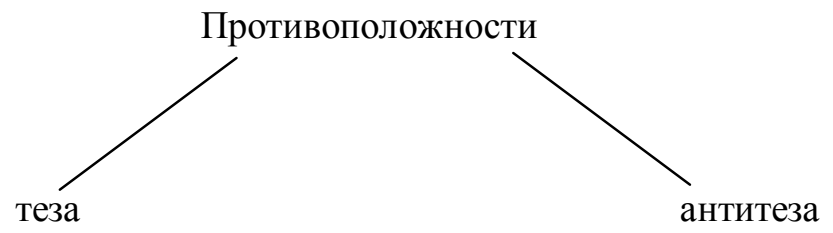


Теза и антитеза составляют двойственность дискрепанции. Две противоположные составные части образуют единство, чаще всего усиливая этим свое прагматическое значение. Два противоположных состояния не исключают друг друга.

Для выражения антонимичных значений имеются разные языковые средства, слова, форманты и т. п. как например, приставки за- и от- для обозначения начинательного и финитивного значения: заговорить $\neq$ отговорить.

12.1. В процессе развития человеческого общества для человека постепенно становится потребностью все более дифференцированно отражать действительность, «структуру действительности», передавать явления (предметы, процессы, действия) в противоположных значениях, и если для этого мы не находим нового средства, используем данное.

Один и тот же языковой элемент, знак может обладать такой потенцией, таким свойством, что он способен выявлять и противоположное ему значение, когда синтагматические свойства значимой языковой единицы вступают в противоречие с денотативным значением этой единицы (ср. МилослАвский 1980: 228). Таковым можно считать, например, противоречие между денотативным значением и синтагматическими свойствами глаголов одноактного способа действия. Суффикс -ну- становится способным выражать и мультипликативное значение. Подобным языковым явлением мы воспринимаем, например, способность делимитативных (временно-уменьшительных) глаголов с приставкой по- развивать посредством вербального контекста значения, противоречащие их основному или главному значению: «посидеть недолго» - «посидеть долго», «поработать немного» - «поработать много» и т. п. Данное языковое явление И. Г. Милославский называет асимметрией языковых элементов, знаков (МилослАвский 1980: 228):

(10) Посидели до глубокой ночи, все обсудили, выпили чай, разошлись в тишине (Ю. Трифонов: Нетерпение, 448).

Клим старался после вечернего чая возможно больще посидеть со взрослыми у потока слов, из которого он черпал мудрость (М. Горький: Жизнь Клима Самгина, I. 18).

12.2. Кроме внешней оппозиции, где противопоставлены и формы, и значения двух разных слов, мы выделяем и так называемую внутреннюю оппозииию, проявляющуюся всегда внутри одного слова. Значения глаголов, выявляющие энантиосемию (внутреннюю оппозицию), объединены чаще всего прагматическим значением. При интердисциплинарном подходе мы рассмотрели, как ведут себя свободные от контекста действия, и как - действия, несвободные от контекста. Этот подход помог нам отъединить внутренние значения от внешних значений видов. Выяснилось, что аспектуальные актанты (субстанциальные элементы), выполняющие либо субъектную, либо объектную функцию, характеризуют глагол не «изнутри», как это утверждает Кацнельсон, а «извне» (см. КРекич 2013: 81), так как результат зависит всегда от факторов, лежащих «вне действия» (ГруБор 1962: 74). 
13. В настоящей статье было рассмотрено соотношение языковых категорий целостности, длительности, определенности и интервала в русских глаголах совершенного вида, т. е. мы занимались новым подходом к вопросу об инварианте совершенного вида. В аспектологии инвариантное значение глаголов СВ толкуется по-разному; не удалось создать единой концепции, добиться тождества взглядов. Причину этого мы усматриваем в том, что даже в кругу специалистов часто сталкиваются такие взгляды, которые на самом деле не противостоят друг другу, не исключают, а напротив, дополняют друг друга. В своей статье мы не ставили целью оспаривать все используемые в аспектологической литературе определения. При определении главного, существенного, т. е. инвариантного значения глаголов СВ мы использовали четыре важных семантических элемента: целостность, длительность, определенность и интервал. Дихотомия Аристотеля предполагает изучение двойственного анализа текста, содержащего в себе главное и побочное, то есть эссенциальное и добавочное (акцессорное) значения.

Как точечно-начинательный глагол, так и точечно-финитивный в своем значении идейно разъединяется, раздваивается, но формально не изменяется. Изменение происходит только в содержательном плане. Первая часть составляет главную, т. е. эссенциальную сторону действия, в то время как акцессорная (процессуальная) сторона передает продолжение начала действия. Вторая, акцессорная часть (атерминативная основа глагола) часто может пропускаться. Вот как истолковывает С. И. Ожегов глагол закричать, образованный от мультипликативного глагола кричать: «1. Крикнуть, издать крик. Закричать от боли; 2. Начать кричать. Закричали ура» (ОжЕгов 1983). Интересно, что Ожегов ставит семельфактивное (одноактное) значение на первое место. По мнению Агрелля, начинательные глаголы первоначально обозначали моментальное действие, и только позднее развили в себе начинательное значение (AGRELL 1908: 79-80).

\section{Литература}

АникинА 1964 = АникинА А. Б. Сочетаемость глаголов совершенного и несовершенного вида с наречиями и другими лексическими единицами, характеризующими способ действия. Филологические науки 1964/3: 165-173.

АПРеСян 1974 = АПРЕСян Ю. Д. Лексическая семантика. Синонимические средства языка. Москва: «Наука», 1974.

АРистотель = АРистотель: Метафизика . http/lib.ru/Poeeast/Aristotel/metaphiz.txt.

БолЛА-ПАЛЛ-ПАПП 1968 = БоЛЛА К., ПАЛЛ Э., ПАПП Ф. Курс современного русского языка. Budapest: Tankönyvkiadó, 1968.

БОНДАРКО-БУЛАНИн 1967 = БОНДАРКО А. В., БУЛАнин Л. Л. Русский глагол. Ленинград: «Просвещение», 1967.

Вригт 1986 = Вригт Г. Х. фон: Логико-философские исследования. Избранные трудыл. Москва: «Прогресс», 1986.

ГловинсКАЯ 1998 = ГлОвинскАЯ М. Я. Инвариант совершенного вида в русском языке. В кн.: Типология вида. Проблемы, поиски, решения. Москва: «Языки русской культуры», 1998. 125-134. 
ГрубоР $1953=$ ГруБоР Ћ. Аспектна значења. Т. 1. Загреб: ЈАЗУ, 1953.

Грубор 1962 = Грубор Дж. Из книги «Видовые значения». В кн.: МАслов Ю. С. (отв. ред.) Вопросы глагольного вида. Москва: «Издательство иностранной литературы», 1962. 68-76.

КАЦНЕЛЬСОН 1972 = КАЦНЕЛЬСОН С. Д. Типология языКа и речевое мышление. Ленинград: «Наука», 1972.

КРЕКИч 1978 = КРЕКИч Й. Соотношение трех основных семантических компонентов глаголов совершенного вида в значении так называемых финитивных глаголов с приставкой om-. Dissertationes Slavicae 13. Szeged, 1978. 113-130.

КРЕКИч 1989 = КРЕКИч Й. Семантика и прагматика временно-предельных глаголов. Изменения значений. Budapest: Tankönyvkiadó, 1989.

КРЕКИч 2013 = КРЕКИч Й. К вопросу о внутреннем и внешнем значениях глаголов совершенного вида. Dissertationes Slavicae. Sectio Linguistica XXX. Szeged, 2013. $75-86$.

МАС 1982 = ЕвГеНьЕВА А. П. (ред.) Словарь русского языка. Т. 2. Москва, 1982.

МАслов 1948 = МАслов Ю. С. Вид и лексическое значение глагола в современном русском литературном языке. Известия АН СССР 1948/4: 303-316.

МАСлов 1958 = МАСлов Ю. С. Роль так называемой перфективаџии и имперфективации в прочессе возникновения славянского глагольного вида. Москва: «Издательство Академии наук СССР», 1958.

МАСлов 1959 = МАСЛОВ Ю. С. Глагольный вид в современном болгарском литературном языке. В кн.: Вопросы грамматики болгарского литературного языка. Москва: «Издательство Академии наук СССР», 1959. 157-312.

МилослАВСКИй $1980=$ МилослАВСКий И. Г. Вопросы словообразовательного синтеза. Москва: «Издательство Московского университета», 1980.

ОЖЕГОВ 1983 = ОЖЕГОВ С. И. Словарь русского языка. Москва: «Русский язЫк», 1983.

ЮХАС 1962 = ЮхАС Й. Заметки о начинательных глаголах в современном русском языке. Dissertationes Slavicae 1. Szeged, 1962. 35-39.

Agrell 1908 = Agrell S. Aspektänderung und Aktionsartbildung beim polnischen Zeitworte. Lund: Håkan Ohlsons Buchdruckerei, 1908.

BELIĆ 1924 = BELIĆ A. Zur slavischen Aktionsart. In: Streitberg Festgabe. Leipzig: Markert \& Petters Verlag, 1924. 1-11.

Bergson 1923 = Bergson H. Idő és szabadság. Budapest: Franklin Társulat, 1923.

Bolberitz 1985 = Bolberitz Pál: Lét és kozmosz. Budapest: Ecclesia, 1985.

HÉvizi 2013 = HÉvizI Ottó: Idő és szinkretizmus. Budapest: Kalligram, 2013.

KÁROLY 1970 = KÁROLY Sándor: Általános és magyar jelentéstan. Budapest: Akadémiai Kiadó, 1970.

KIEFER 2000a = KIEFER Ferenc: Jelentéselmélet. Budapest: Corvina, 2000.

KIEFER 2000b = KIEFER Ferenc: A kognitív nyelvészet: új paradigma? In: A megismeréskutatás útjai. Budapest: Akadémiai Kiadó, 2000. 120-144.

KOSCHMIEDER 1929 = KOSCHMIEDER E. Studien zum slavischen Verbalaspekt. Zeitschrift für vergleichende Sprachforschung 56. Göttingen, 1929. 78-105.

KOSCHMIEDER 1934 = KoSCHMIEDER E. Nauka o aspektach czasownika polskiego w zarysie. Proba syntezy. In: Rozprawy i materjaly wydzialu i towarzystwa przyjaciol nauk $w$ Wilnie. T. 5. Z. 2. Wilno, 1934. 1-240.

KRÉKITS 2011 = KRÉKITS József: Dauer und Prozess in slawischen Verben. Studia Slavica Hung. 56 (2011): 289-294.

MeIllet 1924 = MeIllet A. Le slave commun. Paris: Champion, 1924. 


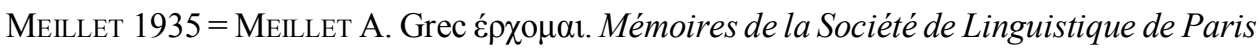
23 (1935): 249-258.

PAPP 1979 = PAPP Ferenc: Könyv az orosz nyelvröl. Budapest: Gondolat, 1979.

PollaK 1962 = PollaK W. Aspekt und Aktionsart im Lichte der Forschungsgeschichte. Moderne Sprachen 6 (1962): 13-22.

Russell 1994 = Russell Bertrand: A nyugati filozófia története. Budapest: Göncöl, 1994.

SCHELJAKIN 1969 = SchelJAKIN M. A. Der Gebrauch der Aspekt- und Tempusformen des Indikativs in der russischen Sprache. Fremdsprachenunterricht 1969/3: 108-120.

VENDler 1967 = VendLer Z. Linguistics in Philosophy. Ithaca, N. Y.: Cornell University Press, 1967.

WiTtGENSTEIN $1960=$ WitTGENSTEIn L. Tractatus logico-philosophicus. Logische-philosophische Abhandlung. Frankfurt am Main: Suhrkamp, 1960.

WiTTGENSTEIN 1989 = WitTGENSTEIn L. Logikai-filozófiai értekezés. Budapest: Akadémiai Kiadó, 1989. 